\section{AIDS by mother-to-child transmission: survival analysis of cases followed from 1983 to 2002 in different regions of Brazil}

\author{
AIDS por transmissão vertical: análise de \\ sobrevivência dos casos acompanhados entre \\ 1983 e 2002 nas diferentes regiões do Brasil
}

\begin{abstract}
Antiretroviral therapy contributes to decreasing morbidity and mortality, and ultimately to increasing survival. In Brazil, there are regional differences in HIV epidemiology regarding pregnant women and children with HIVIAIDS. This study evaluates survival time after AIDS diagnosis in 914 children infected by mother-tochild transmission, reported between 1983 and 1998 and followed until 2002, in Brazil's five regions. Time between birth and HIV diagnosis decreased over the years, mainly in the South and Southeast Regions. There was a significant improvement in survival; more than $75 \%$ of cases were still living four years after diagnosis in the 1997-1998 group. This Brazilian study demonstrates that even with regional inequalities in health care infrastructure it is possible for a developing country to establish an effective system of universal and free access to antiretroviral therapy that produces a significant increase in survival for children with AIDS.
\end{abstract}

Vertical Disease Transmission; HIV; Acquired Immunodeficiency Syndrome; Survival Analysis; Health Inequalities

\author{
Luiza Harunari Matida 1 \\ Alberto Novaes Ramos Jr. 2 \\ José Eduardo Cajado Moncau ${ }^{\dagger}$ \\ Luiz Francisco Marcopito ${ }^{3}$ \\ Heloisa Helena de Sousa Marques ${ }^{4}$ \\ Regina Célia Menezes Succi 5 \\ Marinella Della Negra 6 \\ Norman Hearst 7 \\ Grupo Brasileiro de Estudo da Sobrevida em \\ Crianças com AIDS 8
}

\section{Introduction}

Since the second half of the 1990s, advances in the management of children and adults infected with the human immunodeficiency virus (HIV) all over the world have brought significant changes in the clinical progression of the infection, characterized by lower morbidity of opportunistic conditions and lower mortality from acquired immunodeficiency syndrome (AIDS) 1 .

Greater understanding about viral and cellular dynamics of HIV infection as well as the development of new classes of antiretroviral medication have enabled the introduction and improvement of treatment, achieving efficacy, effectiveness, and efficiency 2,3. In addition, with the expansion and better understanding of prophylaxis for opportunistic diseases, with strategies for reducing mother-to-child HIV transmission, and with broader actions, aimed at giving social support to people living with HIV/AIDS, the beneficial effects of antiretroviral medication have increased 1 .

Unfortunately, the technical and scientific advances of the past 25 years have not benefited or been applied to the majority of the world's HIV infected population 4,5,6. Furthermore, insufficient prevention activities, complicated by the complexity of the health and social context, have meant that the pandemic has continued to grow 7 . 
Different political, social, and economic realities in the various regions of the world influence this epidemic in different ways. One of the most obvious examples is access to antiretroviral therapy; some advances have been made but with unequal distribution ${ }^{8}$. For example, $90 \%$ of the people who need antiretroviral therapy, the majority of whom live in Sub-Saharan Africa, do not receive it 1,9. Different studies have exposed this inequality: the death rate by 15 months of infants with AIDS in European and North American studies is around 5\% 10,11. On the other hand, in Kinshasa (Democratic Republic of Congo), Brazzavile (Republic of Congo), and Kigali (Rwanda) the death rate for infants by one year was from $12 \%-39 \%$, depending on the socioeconomic level and stage of the disease in the mother. The principal causes of death in these children was premature birth, diarrhea, pneumonia, AIDS, and meningitis 12,13.

In Brazil, according to 2005 data from the Brazilian National STD/AIDS Program (PNDST/AIDS), the AIDS epidemic continues its growth among the more socioeconomically vulnerable populations 14 . In spite of standardized recommended protocols for prevention of mother-to-child transmission and antiretroviral therapy in pregnant women 15, important differences in their application have been observed in the different regions of the country 14 .

In the case of mother-to-child HIV transmission, even though the necessary interventions for its reduction are available to all pregnant women and their children, the difficulties faced by the public health care network in making laboratory diagnoses of HIV and insufficient prenatal testing coverage, principally in the most vulnerable part of the population, and the quality of prenatal care, which still leaves much to be desired, result in an under-application of these measures. Nevertheless, in spite of all these difficulties, in the last few years the incidence of AIDS in children has been progressively decreasing in Brazil, albeit in an unequal way 14 .

Overall mortality from AIDS (recorded by the Brazilian Mortality Information System - SIM) has remained steady at around 11,000 deaths per year since 1998, with an average rate of 6.4 deaths per 100,000 population, although growth can still be observed in the Northern and Southern Regions, notably in the State of Rio Grande do Sul, balancing a notable reduction in the rates in the State of São Paulo and the Federal District. The mortality rate among women has also continued growing 14

With the changes that have been occurring in the management of HIV infection, the sustainability of gains in survival needs to be continu- ally monitored. Important indicators of inequality in access include the coverage of preventative and treatment measures and the monitoring of survival time.

Despite their importance, systematic studies of the survival of children with AIDS are scarce in the literature, mainly carried out in developed countries. In Brazil, the PNDST/AIDS has sponsored studies of survival in adults and children to evaluate the national response to the epidemic.

The general objective of this study is to measure survival time after AIDS diagnosis in children between 0 and 12 years of age in five Brazilian regions diagnosed between 1983 and 1998, and followed until 2002.

\section{Method}

This is an historical cohort study of AIDS cases in children under 13 years of age that were included in the Reportable Diseases Database (SINAN), with dates of confirmed diagnoses between January 1, 1983 (year of the first recorded pediatric AIDS), and December 31, 1998.

The sampling process involved the selection of ten Brazilian municipalities: the cities of São Paulo, Riberão Preto, Santos, Campinas, and São José do Rio Preto (São Paulo State); Rio de Janeiro; Porto Alegre (Rio Grande do Sul State); Recife (Pernambuco State); Brasília (Federal District); and Belém (Pará State). The justification for selecting these municipalities was: inclusion of the two largest population centers with the greatest reported number of pediatric AIDS cases, Rio de Janeiro and São Paulo, both in the Southeastern region; inclusion of the city in each of the other regions of Brazil with the greatest number of reported AIDS cases in children (North: Belém; Northeast: Recife; Central West: Brasília; South: Porto Alegre) and four medium-sized cities with a large number of AIDS cases reported in children (Southeast: Santos, Campinas, São José do Rio Preto, and Ribeirão Preto).

At the beginning of the study, these ten cities accounted for $59 \%$ of the total of 5,138 pediatric AIDS cases reported up to December 31, 1998. Of the 3,031 cases reported in these cities during the study period, 351 were found to be ineligible for various reasons. The 2,680 cases that remained served as the base for the sample size calculation.

Reasons for excluding cases from the sample were the following: children who did not fulfill the criteria for being AIDS cases in children under 13 that were in force in Brazil at the time of the study, or those whose did not fulfill the criteria before December 31, 1998; cases registered 
in duplicate or with undefined dates. Of the 121 cases originally reported with the AIDS exposure classification "unknown", 76 (62.8\%) were reclassified as being mother-to-child transmission cases after reviewing their files, and were included in the study; the other 45 were excluded.

Based on the sample size estimated for a statistical power of $90 \%$, a random selection of 1,268 of the 2,680 eligible children was made for the review of medical files and other medical records. This phase was carried out by contacting the health services, locating and surveying the records, transcribing the available information to a specific instrument for the study, and preparing the data base. Among the 1,268 children identified, 1,154 records were located and contained sufficient information for carrying out the study, and, among these, a total of 914 were classified as vertical AIDS transmission and included in this study.

The files and medical records were reviewed by qualified health professionals who had received training in the requirements for the study. This review process took place between May 2000 and January 2002. The survival analysis of this sample sought to analyze the occurrence of death as an outcome in relation to the period of time that began with the diagnosis of AIDS. Therefore, the date of AIDS diagnosis for each case was re-evaluated, based on the criteria for AIDS at the time of diagnosis. The date of death was established through evaluation of the medical record and/or local mortality data when available. For children whose vital status was unknown, the date of censure was defined as their last recorded clinic visit.

A data base was constructed and analyzed using SPSS 12.0 for Windows (SPSS Inc., Chicago, U.S.A.). A descriptive analysis of the variables was carried out with the objective of characterizing the study sample. Survival curves since the date of AIDS diagnosis for all types of mortality were constructed utilizing the Kaplan-Meier estimator $16,17,18$, which permits estimating survival probability. Comparison of survival curves by region, sex, and year of diagnosis was carried by means of a log-rank test or Breslow test 18,19 . In all statistical analyses a significance level of 0.05 was used, meaning that associations with a $p$ value less than 0.05 were considered significant.

This study was approved by the Research Ethics Commitee of the Program of STD and AIDS of the State of São Paulo and the Escola Paulista de Medicina, Universidade Federal de São Paulo [Paulista School of Medicine, Federal University of São Paulo], following the standards established in Resolution $n^{o}$. 196/96 of the National Health Council.

\section{Results}

The 914 cases selected (Table 1) were from six federal units that represent the five major regions of the country and that account for the majority of reported cases $(69.9 \%)$. Over the time period studied, there was a significant improvement in survival time among Brazilian children with AIDS infected through mother-to-child transmission (Figure 1), as has already been presented in a previous publication 20 . The median survival in cases diagnosed before 1988 was 20 months; this increased to 24 months in cases diagnosed between 1988 and 1992, and to 50 months in cases diagnosed between 1993 and 1994. A median survival time could not be calculated for the cases more recently diagnosed, as more than $50 \%$ were still alive at the end of the study period, and more than $75 \%$ of the cases were still alive four years after diagnosis among cases diagnosed in 1997 and 1998.

After 60 months, the probability of a being alive was $52.1 \%$ (95\%CI: 48.4-55.7). For males (50.1\% of cases), it was $51.2 \%$ (95\%CI: $46.1-56.3$ ), and for females (49.9\% of cases), it was $52.8 \%$ (95\%CI: 47.7-57.9).

Table 1 shows that the State of São Paulo had the majority (87.5\%) of the earliest cases diagnosed, and also is the state that shows the greatest reduction in the number of cases in the most recent period analyzed. The time from birth to diagnosis of HIV infection shows an important reduction over time, which indicates better access to diagnosis and care, mainly in the South and Southeast.

Regarding the cases from the States of Pará and Pernambuco and the Federal District, because they were small samples, representing only $10 \%$ (92) of the cases, the results are mainly of descriptive value.

In Figure 2, the survival curves of the Federal units of Pará, Pernambuco, and the Federal District are presented together because they represent a small number of cases, and also because the majority of the cases were diagnosed in the most recent period studied. After the date of AIDS diagnosis, the median survival time was not reached in the cases sampled in Pará, Pernamuco, and the Federal District. In other words, by December, 31, 2001, the probability of survival was greater than $50 \%$ in these cohorts.

Despite the difficulty of adequate observation time, Figures 2 and 3 show significant differences in survival times by location among cases sampled in the five states and the Federal District: 93 months in the State of Pará; 122 months in the Federal District; 124 months in the State of Pernambuco; 133 months in the State of Rio de 
Characteristics of 914 cases of vertical HIV transmission, diagnosed in the period between 1983 and 1998 in Brazil.

\begin{tabular}{|c|c|c|c|c|c|c|c|c|c|c|c|c|}
\hline & \multicolumn{12}{|c|}{ States } \\
\hline & \multicolumn{2}{|c|}{$\begin{array}{c}\text { Pará } \\
(n=19)\end{array}$} & \multicolumn{2}{|c|}{$\begin{array}{l}\text { Pernambuco } \\
\qquad(n=39)\end{array}$} & \multicolumn{2}{|c|}{$\begin{array}{l}\text { Federal District } \\
\qquad(n=34)\end{array}$} & \multicolumn{2}{|c|}{$\begin{array}{l}\text { São Paulo } \\
(n=533)\end{array}$} & \multicolumn{2}{|c|}{$\begin{array}{l}\text { Rio de Janeiro } \\
\qquad(n=130)\end{array}$} & \multicolumn{2}{|c|}{$\begin{array}{l}\text { Rio Grande do Sul } \\
\qquad(n=159)\end{array}$} \\
\hline & $n$ & $\%$ & $\mathrm{n}$ & $\%$ & $\mathrm{n}$ & $\%$ & $n$ & $\%$ & $n$ & $\%$ & $\mathrm{n}$ & $\%$ \\
\hline \multicolumn{13}{|l|}{ Sex } \\
\hline Masculine & 12 & 63.2 & 17 & 43.6 & 17 & 50.0 & 284 & 53.3 & 54 & 41.5 & 74 & 46.5 \\
\hline Feminine & 7 & 36.8 & 22 & 56.4 & 17 & 50.0 & 249 & 46.7 & 76 & 58.5 & 85 & 53.5 \\
\hline \multicolumn{13}{|c|}{ Year of diagnosis } \\
\hline Before 1988 & - & - & - & - & - & - & 14 & 2.6 & - & - & 2 & 1.3 \\
\hline 1988-1992 & 1 & 5.3 & 9 & 23.1 & 10 & 29.4 & 184 & 34.5 & 31 & 23.8 & 30 & 18.9 \\
\hline 1993-1994 & 3 & 15.8 & 6 & 15.4 & 4 & 11.8 & 124 & 23.3 & 20 & 15.4 & 39 & 24.5 \\
\hline 1995-1996 & 4 & 21.1 & 10 & 25.6 & 7 & 20.6 & 134 & 25.1 & 29 & 22.3 & 37 & 23.3 \\
\hline \multirow[t]{2}{*}{ 1997-1998 } & 11 & 57.9 & 14 & 35.9 & 13 & 38.2 & 77 & 14.4 & 50 & 38.5 & 51 & 32.1 \\
\hline & n & Month & $\mathrm{n}$ & Months & $\mathrm{n}$ & Month & n & Month & $\mathrm{n}$ & Month & $\mathrm{n}$ & Months \\
\hline \multicolumn{13}{|c|}{ Median time (months) after } \\
\hline \multicolumn{13}{|c|}{ birth for HIV diagnosis } \\
\hline 1979-1986 & - & - & 3 & 111.8 & - & - & 34 & 52.6 & 10 & 111.3 & 8 & 79.2 \\
\hline 1987-1989 & 1 & 100.9 & 8 & 35.5 & 4 & 42.4 & 119 & 23.3 & 22 & 43.9 & 11 & 33.6 \\
\hline 1990-1991 & 2 & 32.7 & 7 & 35.7 & 8 & 7.9 & 115 & 11.4 & 31 & 31.4 & 26 & 17.8 \\
\hline 1992-1993 & 8 & 48.1 & 3 & 26.7 & 9 & 36.8 & 104 & 13.6 & 19 & 32.8 & 32 & 7.1 \\
\hline 1994-1995 & 6 & 25.3 & 9 & 13.4 & 7 & 18.8 & 102 & 7.8 & 22 & 24.5 & 41 & 9.4 \\
\hline 1996-1998 & 2 & 17.6 & 9 & 18.3 & 6 & 18.5 & 59 & 4.7 & 26 & 7.2 & 41 & 7.0 \\
\hline
\end{tabular}

Janeiro; 134 months in the State of Rio Grande do Sul; and 154 months in the State of São Paulo. These results should be interpreted with consideration of the different distribution of reporting dates (Table 1), which might contribute to differences in survival by location.

In Figure 3 there is a significant difference in the three curves shown $(\mathrm{p}=0.003)$. Comparing only the two curves for Rio de Janeiro and São Paulo does not result in a statistically significant difference $(p=0.266)$.

\section{Discussion}

Brazil was one of the first countries to adopt policies to provide access to quality healthcare for carriers of the HIV virus. These strategies are manifested in the Law of Industrial Property ( Law $n^{o} .9$,279) and through Law $n^{o} .9,313$, which set out in 1996, that it is the obligation of the State to distribute universally, and free of charge, medication for the treatment of HIV and AIDS patients. The number of medications was gradually increased as they were approved by the Advisory Committees for Antiretroviral Therapy 15,21,22.
As a result of this policy, the country has seen a significant reduction in mortality and in the number of hospitalizations caused by opportunistic diseases 14 . On the other hand, geographically, there is a heterogeneity in the distribution and quality of services, with a concentration in the South and Southeast and difficulties in the North and Northeast. Survival studies can help to measure these epidemiological and operational differences and quantify differences in health care in the country.

Survival time, aside from being an important measure for public policy, is fundamental for the monitoring and evaluation of intervention strategies adopted with the aim of prolonging the lives of HIV infected people. Survival is strongly influenced by the availability and performance of the health service network in different ways.

Access to healthcare and prevention services, screening programs, the availability of complementary diagnostic methods, and specific treatment, clearly impact the natural history of the disease, resulting in improved survival that can increase or diminish according to the level and quality of application of these interventions. With the evolution of technical and scien- 


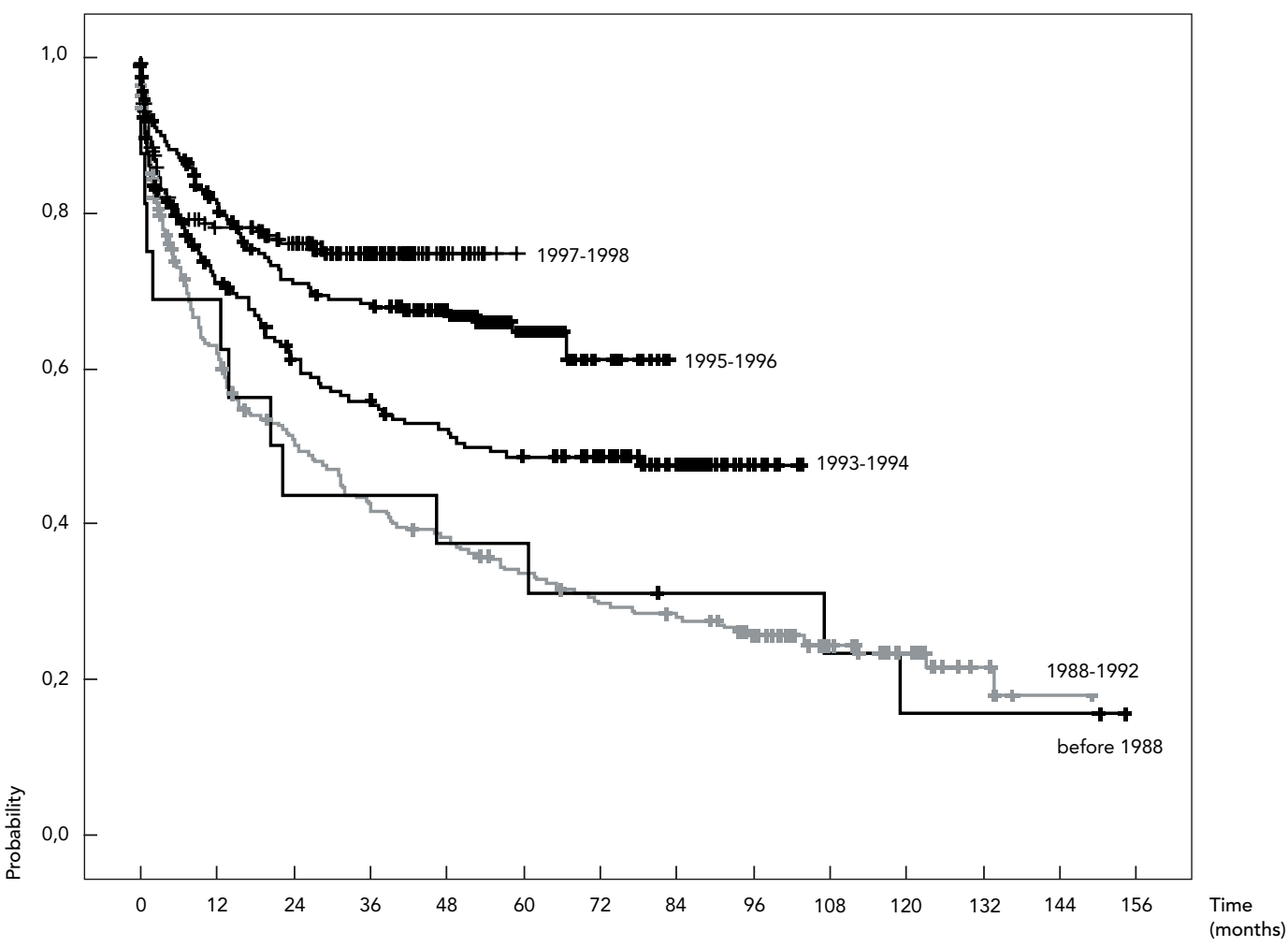

tific knowledge, the median time between AIDS diagnosis and death has changed dynamically over time. This study demonstrates differences in this process among federal units analyzed.

Some studies showed a mortality of between $25 \%$ and $50 \%$ in the first year of life of HIV-infected babies and of $85 \%$ to $95 \%$ during the first five years of life before the adoption of antiretrovirals 23,24 . More recent data about the natural history of mother-to-child HIV infection indicate that the average time of survival has now increased to between 6 and 9 years 25 .

Chequer et al. 26 recorded a median survival time of 5.1 months among 2,135 adult AIDS cases reported between 1982 and 1989. In the State of São Paulo, that reported $47 \%$ of cases of AIDS in the country, Grangeiro et al. 27 observed an average survival time between 1985 and 1991 of 232 days, with a variation by diagnostic category from 201 days (mother-to-child transmission) to 259 days (hemophilia) in 7,480 reported cases. Another study, also from the State of São Paulo, with 1,066 children infected by vertical transmission compared the periods from 1988 to 1991 and from 1992 to 1994, with the period before 1987. The relative risk of death in the period from 1988 to 1991 was 0.59 (95\%CI: $0.37-0.96$ ) while that of the period from 1992 to 1994, when antiretroviral therapy had begun to be available, was 0.45 (95\%CI: $0.28-0.72){ }^{28}$. In the city of New York, deaths from AIDS among adults were reduced by $72 \%$ between the years 1994 and 199811.

High potency antiretroviral treatment has made a substantial contribution to the decline of the incidence of opportunistic infections among HIV infected patients, with a resulting decrease in morbidity and mortality 29 . The new schemes of antiretrovirals have proven their effectiveness in diminishing viral load, in increasing CD4 T lymphocyte count, and have substantially altered the natural course of HIV infection 2,3 .

Toxicity associated with the long-term use of antiretrovirals has to be considered when be- 
Survival after AIDS diagnosis in cases of vertical transmission in the Brazilian States of Pará, Pernambuco and the Federal

District, during the period from 1983 to 1998, and followed until 2002.

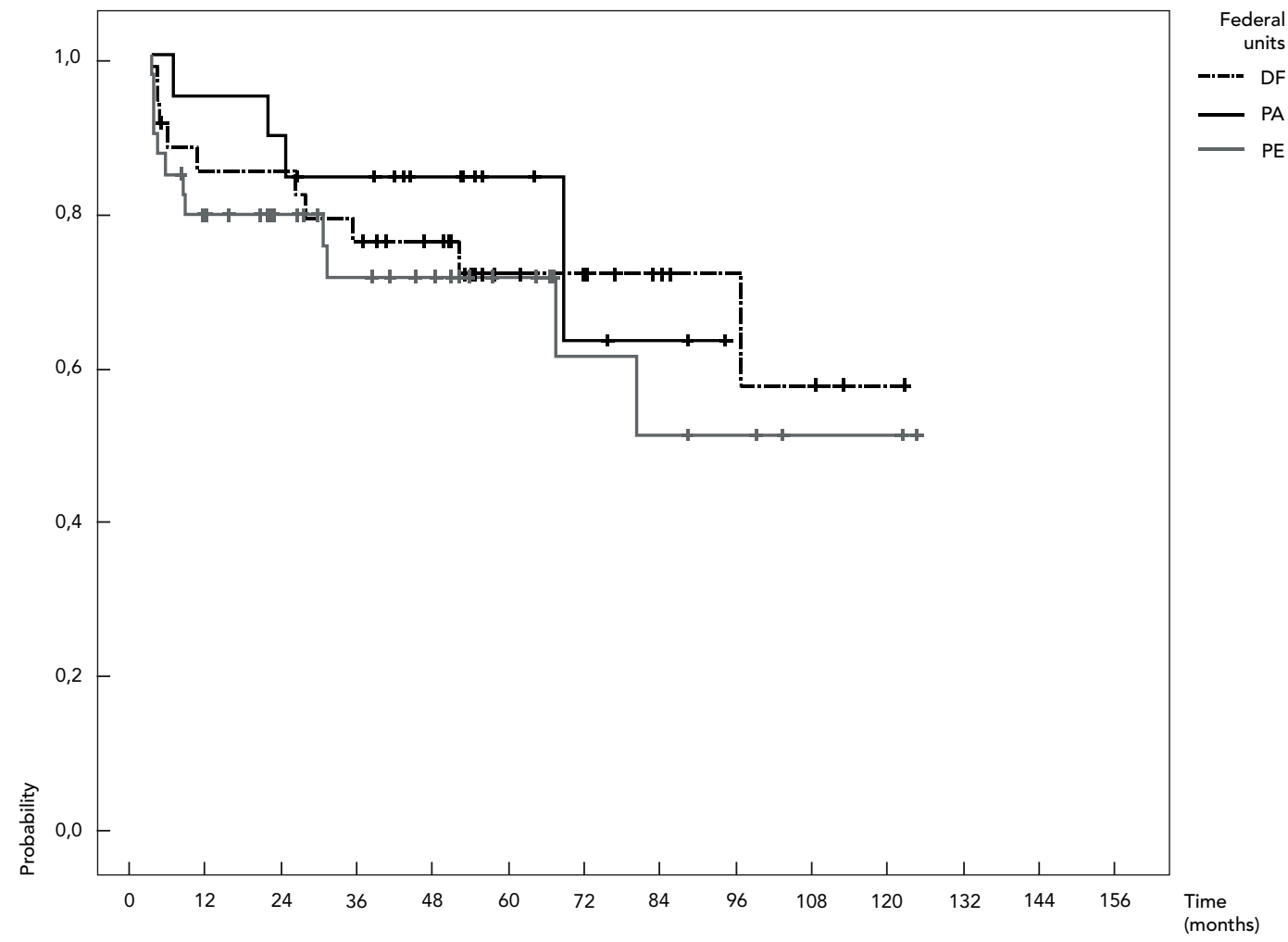

Breslow test for comparison of the three curves: $p=0.510$.

ginning treatment, sometimes precociously, in clinically stable children with a relatively preserved immune system 30 . Aside from this, the appearance of antiretroviral-resistant HIV strains and problems of adherence to therapy represent two of the major causes for treatment failure 31 . Future studies should help to identify more effective and reliable therapeutic strategies, with a consequent increase in survival.

Starting in the second half of the 1990s, there was a significant reduction in mother-to-child transmission in the United States 32 . This was also observed in Brazil starting in 1998 14, as well as an increase in survival to the period of adolescence and adulthood in the population of HIV infected children. The majority of these children and adolescents receive long-term antiretroviral therapy 33

Among children infected by mother-tochild transmission, mortality was reduced $67 \%$ between 1997 and 2002, parallel to the growth in the use of triple or quadruple antiretroviral medication. Progression to AIDS and rates of hospitalization have also fallen substantially. But in spite of an $80 \%$ decrease in the rates of hospitalizations, the absolute number of hospitalizations only decreased $25 \%$; the growing numbers of children infected with HIV who need care because of complications, principally in the North, Northeast, and South of the country, require better evaluation, prophylaxis, and treatment 14,22 .

Survival of HIV infected children has been analyzed in various cohorts around the world $10,34,35$, demonstrating the impact antiretrovirals have on time and quality of survival, and re-emphasizing the importance of access of all socioeconomic strata to these medications 6,36 .

Brazil has also experienced a significant increase in survival of children with AIDS 20. In this 
Survival after AIDS diagnosis in cases of vertical transmission from the Brazilian States of Rio de Janeiro, Rio Grande do Sul, and São Paulo, during the period from 1983 to 1998, and followed until 2002.

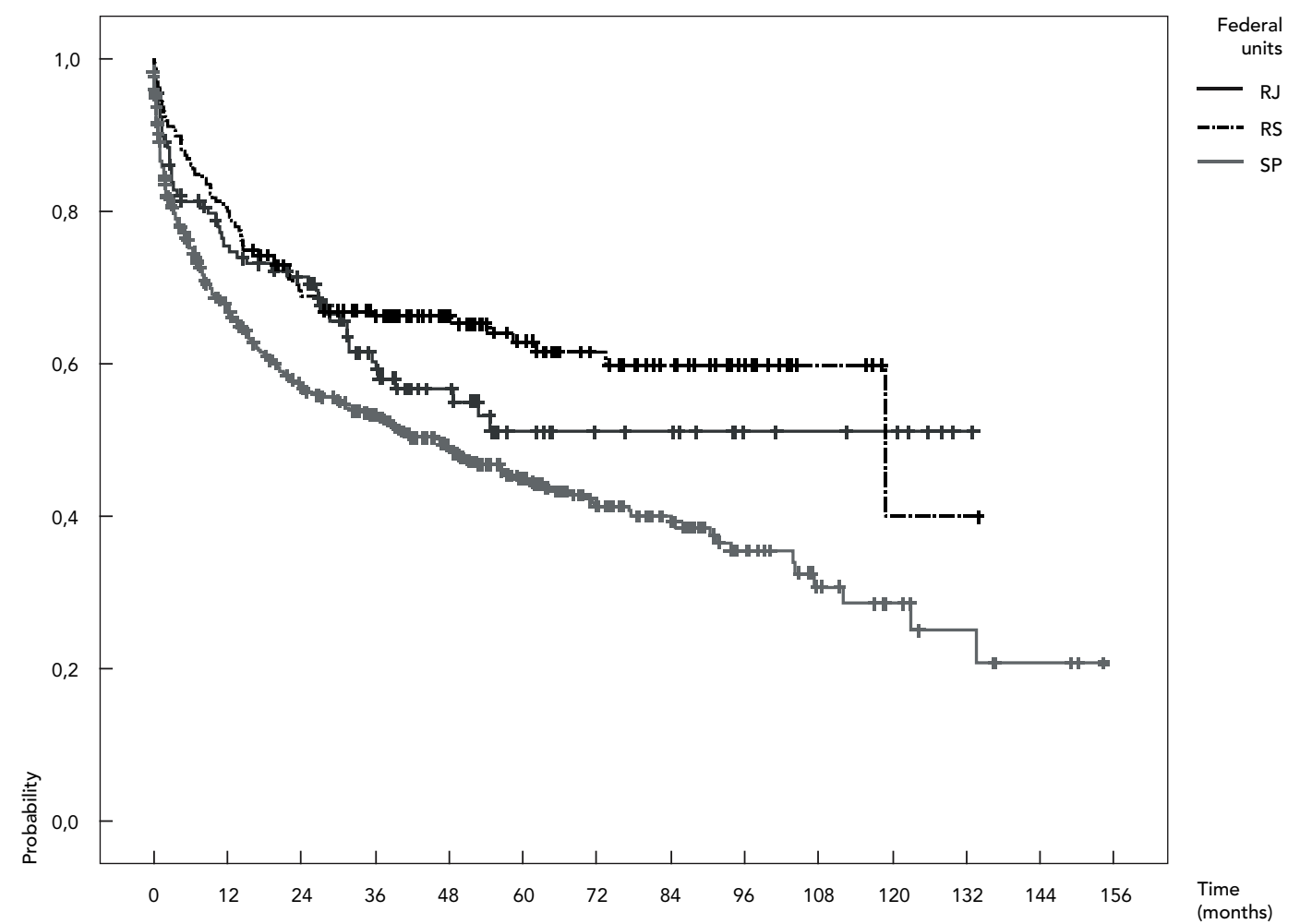

Breslow test for comparison of the three curves: $p=0.003$.

study, over the lengthy period analyzed, there was a significant improvement in the survival time among Brazilian children with AIDS that had been infected by mother-to-child transmission; more than $75 \%$ of the cases were still living four years after diagnosis among those cases diagnosed in 1997 and 1998.

The national results 20,28 of survival since the date of diagnosis of AIDS in cases of mother-tochild transmission are similar to those reported in the United States, where among cases diagnosed in 1998 , the survival to 36 months was $87 \% 37$.

Other studies demonstrate a similar increase in survival, even though the degree of improvement and the actual levels of survival attained are difficult to compare. The majority of accounts of survival time among cases of AIDS through mother-to-child transmission are based on cohorts of HIV infected children who were diagnosed at birth or immediately afterwards. Survival time is normally calculated from date of birth or date of HIV infection diagnosis instead of the date of meeting the criteria for AIDS case definition, thus affecting the reported time of survival. For example, survival until the age of five years in Canadian children infected via mother-to-child transmission increased from $72 \%$ among those born during the period between 1992 and 1995 to $92 \%$ among those born in $1996{ }^{38}$. In the United States, survival until five years increased from $72 \%$ to $83 \%$ when comparing children born before and after 199439 .

The present study was based on national AIDS reporting data, and this method has the advantage of being representative of the population of this age group and transmission method. Regarding cases that were not reported until the criteria for AIDS were met, it is only possible to make unbiased estimates about survival starting from this point. Adding together the median age of AIDS diagnosis plus the median survival after the diagnosis gives an estimate of median survival after 
birth. But this would be an underestimate insofar as healthier infected children that were not diagnosed or still had not fulfilled the AIDS case criteria are not included in the denominator.

This situation could change in the future in Brazil, because since 2000 strategies for the reduction of mother-to-child transmission have made the inclusion of all pregnant women and children exposed to HIV in the SINAN registry a norm.

Despite the fact that the ten cities selected are representative from a geographical point of view and are responsible for the majority of Brazilian reported AIDS cases in children, it is possible that under-reporting may be higher and that absolute survival, as well as recent improvements in survival, may be lower in other areas of Brazil. It is estimated that under-reporting of AIDS is relatively low in Brazil 40, but the cases not reported could have a lower survival time, as may have occurred in $16 \%$ of the original sample of this study, for which there was no information available. Even though these factors could generate an overestimate of survival, they could not have caused the increase that has been observed in survival, unless the magnitude of the bias has increased substantially over time.

One factor that could have influenced survival time is early diagnosis. The definition for AIDS cases in Brazil was reviewed in 1994 and made more sensitive, even though the T cell CD4+ lymphocyte count only became widely available in 199741 . On the other hand, the improvement of initial treatment helps retard the progression of the disease, consequently contributing to an increase in survival and to a delay in meeting the case criteria for AIDS.

Frequently the reporting of an AIDS case occurs very close to, or even after, death. This creates an important problem for survival analyses, in that the inclusion of these patients produces a bias by systematically reducing the survival period observed. Nevertheless, we have followed the procedures used in many other studies by including these cases, even though this results in shorter observed survival times 42 .

The most important methodological problem in survival studies is the validity of the underlying data. This includes questions such as: AIDS case definition and its evolution over time; coverage (sensitivity) and quality (specificity) of the case registries; quality of clinical management; definition of date of AIDS diagnosis, and access to health services. Of principal influence are the last factors cited, as can be seen in the results of this study, considering that the Southeast and South regions present, as much as possible, better healthcare for the carriers of this disease. But it is still necessary to carry out further studies to better understand regional inequities.

\section{Conclusions}

Even though there has been a reduction in mother-to-child transmission and the Brazilian Unified National Health System (SUS) offers free prenatal care, HIV testing, and treatment for AIDS, as well as interventions with Zidovudine (AZT) at the time of delivery for the infected expectant mothers and exposed babies, it can be observed that opportunities for prenatal detection of HIV infection are still being missed. This makes the control of AIDS acquired by mother-to-child transmission more difficult, as shown in a recent study of mother-to-child HIV transmission rates in the different regions of Brazil 43.

In spite of limitations, this study covered different phases of the epidemic, different case definitions, and different therapy schemes for treatment and prophylaxis of opportunistic infections. The results suggests that the mortality rate was falling both during and after the period that corresponds to the introduction of antiretroviral therapy and development of clinical monitoring in Brazil. On the other hand, the inequalities observed in survival time reflect the real epidemiological and operational context of the country.

The advent of new therapeutic options for HIV, along with better knowledge of viral behavior and of the body's response to infection, point to the need for continuous improvements in therapeutic schemes and duration.

Because of the increase in survival of children, coordination and exchange of information with healthcare services which treat adults with HIV/AIDS are increasingly important, to meet the medical, social, and psychological needs of children who are beginning their adolescent and adult phases of life. In any case, as children and adolescents receiving antiretroviral therapy proceed to the hormonal changes and growth associated with puberty, the long term complications and toxicities from chronic exposure to antiretroviral therapies will require careful monitoring and evaluation.

Analysis of the Brazilian experience is important, as it demonstrates that it is possible for a developing country with great geographical extension to establish an effective system for the universal and free access to antiretroviral therapy. It also demonstrates that such care, even in a country that presents regional difficulties for the organization of an ideal healthcare infrastructure, can make a significant difference in survival. 


\section{Resumo}

A terapia anti-retroviral contribui para a diminuição da morbidade e da mortalidade, com conseqüente aumento da sobrevida. No Brasil, há diferenças regionais relativas à dinâmica da epidemia do HIV e ao seu enfrentamento no grupo das gestantes e das crianças com HIVIAIDS. Este estudo verifica o tempo de sobrevida após o diagnóstico de AIDS em 914 crianças infectadas por transmissão vertical, entre os anos de 1983 e 1998, e acompanhadas até 2002, nas cinco regiões brasileiras. O tempo do nascimento ao diagnóstico de infecção pelo HIV, ao longo dos anos, apresenta uma diminuição, principalmente nos estados das regiões Sul e Sudeste. Houve melhora significativa da sobrevivência, mais de 75\% dos casos ainda estavam vivendo quatro anos após o diagnóstico, no grupo de 1997 e 1998. Esta análise brasileira mostra ser possível para um país em desenvolvimento estabelecer um sistema efetivo de acesso gratuito e universal à terapia anti-retroviral, mesmo com dificuldades regionais para a organização de uma infra-estrutura ideal de saúde, tendo como resultado um aumento significativo da sobrevivência.

Transmissão Vertical de Doença; HIV; Síndrome de Imunodeficiência Adquirida; Análise de Sobrevida; Desigualdades em Saúde

\section{Contributors}

L. H. Matida and N. Hearst were responsible for the design and analysis of the study and in the preparation of the manuscript. L. H. Matida and A. N. Ramos Jr. were responsible for reviewing the literature and editing the article. J. E. C. Moncau, L. F. Marcopito, H. H. S. Marques, R. C. M. Succi, M. D. Negra and the Grupo Brasileiro de Estudo da Sobrevida em Crianças com AIDS participated in writing and editing process.

\section{Other members of the Grupo Brasileiro de Estudo da Sobrevida em Crianças com AIDS}

J. C. Apolinário Jr., A. Barbosa Jr., D. V. Bertolini, S. Caminada, A. M. M. Castro, M. C. Cervi, B. V. Costa, A. Guibu, P. Guzzo, I. M. A. S. Landroni, D. M. Machado, N. J. S. Santos, H. K. Sato, M. M. Sauer, C. L. O. Silva e E. S. Souza (2002). M. G. P. Fonseca e E. Waldman (2006).

\section{Acknowledgments}

The study was financed by the Brazilian National STD/ AIDS Program (PNDST/AIDS), Health Survillance Secretariat, Brazilian Ministry of Health. The authors would like to thank all the members of the Grupo Brasileiro de Estudo da Sobrevida em Crianças com AIDS [Brazilian Survival Study Group on Children with AIDS], without whom this study would not have been possible; the PNDST/AIDS and the Program of STD and AIDS of the State of São Paulo de São Paulo that gave technical support; as well as the Faculdade de Medicina da Santa Casa de São Paulo [School of Medicine, São Paulo Mercy Hospital] that gave administrative support.

\section{References}

1. The Joint United Programme on HIV/AIDS. AIDS epidemic update, December 2005. Geneva: Joint United Nations Programme on HIV/AIDS/World Health Organization; 2005.

2. Mocroft A, Ledergerber B, Katlama C, Kirk O, Reiss P, D'Arminio MA, et al. Decline in the AIDS and death rates in the EuroSIDA study: an observational study. Lancet 2003; 362:22-9.

3. Resino S, Bellón JM, Resino R, Navarro ML, Ramos JT, José MI, et al. Extensive implementation of highly active antiretroviral therapy shows great effect on survival and surrogate markers in vertically HIV-infected children. Clin Infect Dis 2004; 38:1605-12.

4. Murray CJ, Lopez AD. Mortality by cause for eight regions of the world: global burden of disease study. Lancet 1999; 349:1269-76.

5. Houweling TA, Kunst AE, Malkenbach JP. World Health Report 2000: inequality index and socioeconomic inequalities in mortality. Lancet 2001; 357:1671-2.
6. Wood E, Montaner JS, Chan K, Tyndall MW, Schechter MT, Bangsberg D, et al. Socioeconomic status, access to triple therapy, and survival from HIV-disease since 1996. AIDS 2002; 16:2065-72.

7. Shapiro K, Benatar SR. HIV prevention research and global inequality: steps towards improved standards of care. J Med Ethics 2005; 31:39-47.

8. Poundstone KE, Strathdee SA, Celentano DD. The social epidemiology of human immunodeficiency virus/acquired immunodeficiency syndrome. Epidemiol Rev 2004; 26:22-35.

9. The Joint United Programme on HIV/AIDS. AIDS epidemic update, December 2004. Geneva: Joint United Nations Programme on HIV-AIDS/World Health Organization; 2004

10. Gortmaker SL, Hughes M, Cervia J, Brady M, Johnson GM, Seage GR, et al. Effect of combination therapy including protease inhibitors on mortality among children and adolescents infected with HIV-1. N Eng J Med 2001; 345:1522-8. 
11. Fordyce EJ, Singh TP, Nash D, Gallagher B, Forlenza S. Survival rates in NYC in the era of combination ART. J Acquir Immune Defic Syndr 2002; 30:111-8.

12. Popp D, Fisher JD. First, do no harm: a call for emphasizing adherence and HIV prevention interventions in active anti-retroviral therapy programs in the developing world. AIDS 2002; 16:676-8.

13. United Nations Children's Fund. Progress for children, volume 1; 2004. http://www.unicef. org/progressforchildren/2004v1 (accessed on 30/ Mar/2006).

14. Ministério da Saúde. Apresentação. Boletim Epidemiológico AIDST 2005; Ano II; $\mathrm{n}^{\circ} .1$.

15. Ministério da Saúde. Recomendações para profilaxia da transmissão vertical do HIV e terapia anti-retroviral em gestantes. Brasília: Ministério da Saúde; 2004.

16. Kaplan EL, Meier P. Non parametric estimation from incomplete observation. J Am Stat Assoc 1958; 53:457-81.

17. Lee LM, Karon JM, Selik R, Neal JJ, Fleming PL. Survival after AIDS diagnosis in adolescents and adults during the treatment era, United States, 1984-1997. JAMA 2001; 285:1308-15.

18. Kleinbaum DG. Survival analysis: a self-learning text. New York: Springer-Verlag; 1995.

19. Cox DR, Oakes D. Analysis of survival data. London: Chapman \& Hall; 1984.

20. Matida LH, Marcopito LF, Succi RCM, Marques HHS, Della Negra M, Grangeiro A, et al. Improving survival among Brazilian children with perinatalacquired AIDS. Braz J Infect Dis 2004; 8:419-23.

21. Ministério da Saúde. Recomendações para terapia anti-retroviral em crianças infectadas pelo HIV. Brasília: Ministério da Saúde; 2004.

22. Ministério da Saúde. Recomendações para terapia anti-retroviral em adultos e adolescentes. Brasília: Ministério da Saúde; 2004.

23. European Collaborative Study. Natural history of vertically acquired human immunodeficiency virus-1 infection. Pediatrics 1994; 94:815-9.

24. Tovo P, Gabiano C, Palomba E, De Martino M, Galli L, Capello N, et al. Prognostic factors and survival in children with perinatal HIV-1 infection. Lancet 1992; 339:1249-53.

25. Grubman S, Gross E, Lerner-Weiss N, Hernandez M, McSherry GD, Hoyt LG, et al. Older children and adolescents living with perinatally acquired human immunodeficiency virus infection. Pediatrics 1995; 95:657-63.

26. Chequer P, Hearst N, Hudes ES, Castilho E, Rutherford G, Loures L, et al. Determinants of survival in adult Brazilian AIDS patients, 1982-1989. AIDS 1992; 6:483-7.

27. Grangeiro A. O perfil sócio-econômico dos casos de AIDS na cidade de São Paulo. In: Parker R, Bastos C, Galvão J, Pedrosa JS, organizadores. A AIDS no Brasil. Rio de Janeiro: Editora Relume-Dumará; 1994. p. 91-128.

28. Matida LH. AIDS de transmissão materno-infantil: análise de sobrevivência dos casos notificados ao sistema oficial do Estado de São Paulo de 1987 a 1994. Rev Paul Pediatr 1999; 17:37-43.

29. Saulsbury FT. Resolution of organ-specific complications of human immunodeficiency virus infection in children with use of highly active antiretroviral therapy. Clin Infect Dis 2001; 32:464-8.
30. Cooper CL, Parbhakar MA, Angel JB. Hepatotoxicity associated with antiretroviral therapy containing dual versus single protease inhibitors in individuals coinfected with hepatitis $\mathrm{C}$ virus and human immunodeficiency virus. Clin Infect Dis 2002; 34:1259-63.

31. Richman DD, Morton SC, Wrin T, Hellman N, Berry S, Shapiro MF, et al. The prevalence of antiretroviral drug resistance in the United States. AIDS 2004; 18:1393-401.

32. Lindegren ML, Byers Jr. RH, Thomas P, Davis SF, Caldwell B, Rogers M, et al. Trends in perinatal HIV/ AIDS in the United States. JAMA 1999; 282:531-8.

33. Abrams E, Weedon J, Bertolli J, Bornschlegel K, Cervia J, Mendez $\mathrm{H}$, et al. Aging cohort of perinatally human immunodeficiency virus-infected children in New York City. Pediatr Infect Dis J 2001; 20:511-7.

34. De Martino M, Tovo P, Balducci MD, Galli L, Gabiano C, Rezza G, et al. Reduction in mortality with availability of anti-retroviral therapy for children with perinatal HIV-1 infection. JAMA 2000; 284:190-7.

35. Dunn D. Short-term risk for disease progression in HIV-1 infected children receiving no anti-retroviral therapy or zidovudine monotherapy: a meta-analysis. Lancet 2003, 362:1605-11.

36. Rapiti E, Porta D, Forastiere F, Fusco D, Perucci C. Socioeconomic status and survival of persons with AIDS before and after the introduction of highly active antiretroviral therapy. Lazio AIDS Surveillance Collaborative Group. Epidemiology 2000; 11:496-501.

37. Centers for Disease Control and Prevention. Survival after AIDS diagnosis. Atlanta: Centers for Disease Control and Prevention; 2002. (HIV/AIDS Surveillance Report, 14).

38. King SM. Progression of disease in HIV infected children slowed after the first year of life. Evid Based Med 2002; 7:27.

39. Barnhart HX, Caldwell MB, Thomas P, Mascola L, Ortiz I, Hsu WH, et al. Natural history of human immunodeficiency virus disease in perinatally infected children: an analysis from the Pediatric Spectrum of Disease Project. Pediatrics 1996; 97:710-6.

40. Ministério da Saúde. Sobre a correção do atraso de notificação dos casos de AIDS no Brasil. Boletim Epidemiológico AIDS 2001; Ano XIV; no. 2.

41. Ministério da Saúde. Perspectiva histórica das definições de caso de AIDS no Brasil. Boletim Epidemiológico AIDS 2004; Ano XVII; no. 1.

42. Menesia EO, Costa Passos AD, Monteiro, ME, DalFabbro AL, Laprega MR. Survival of AIDS patients in a city in southeastern Brazil. Rev Panam Salud Pública 2001; 10:29-36.

43. Succi RCM; Grupo de Estudos da Sociedade Brasileira de Pediatria. Transmissão vertical do HIV no Brasil em 2003-2004: resultado preliminar de um estudo colaborativo multicêntrico. In: XIV Congresso Brasileiro de Infectologia Pediátrica e III Jornada Paranaense de Infectologia Pediátrica. Recife: Sociedade Brasileira de Pediatria; 2006. p. S100.

Submitted on 15/May/2006

Final version resubmitted on 11/Aug/2006

Approved on 31/Aug/2006 